Received: 04.05.2021

Accepted: 12.06.2021

Dokuz Eylül University

Published Online: 31.12.2021

DOI: $10.18613 /$ deudfd.932650

Maritime Faculty Journal

Review Article

Vol:13 Issue:2 Year:2021 pp:299-316

ISSN:1309-4246

E-ISSN: 2458-9942

\title{
THE HISTORICAL PROCESS OF THE DIESEL ELECTRIC PROPULSION SYSTEM
}

\author{
Murat PAMIK ${ }^{1}$ \\ Mustafa NURAN²
}

\begin{abstract}
Increasing in harmful gas emissions caused by the use of fossil fuels harms the environment that is difficult to recover. Regulations are being implemented in order to reduce these effects in the maritime field and it is getting harder and also tough to adapt these constantly developed regulations with the existing conventional propulsion systems. Especially considering environmental factors, technological developments in conventional propulsion systems reach a certain saturation and become insufficient so that researchers have turned to work in the field of electrical propulsion systems. In this study, development of the DieselElectric (DE) propulsion system, which has an important place in EPS, throughout the historical process and its comparison with other EPS are applied. According to the results obtained, DE propulsion system can be applied to many ship types, furthermore, this system provides gains in terms of $\mathrm{NO}_{X}, \mathrm{SO}_{X}$ and $\mathrm{CO}_{2}$ emissions, energy efficiency, fuel consumption, life cycle and cost. However, the initial investment cost is the biggest shortcoming of DE propulsion system.
\end{abstract}

Keywords: Electrical Propulsion Systems, Diesel-Electric Propulsion System, Emissions, Fuel Consumption, Cost Efficiency

1 İzmir, Dokuz Eylül Üniversitesi, Denizcilik Fakültesi, Araş.Gör.Dr., murat.pamik@deu.edu.tr Orcid: 0000-0003-3268-1368

2 İzmir, Dokuz Eylül Üniversitesi, Denizcilik Fakültesi, Dr. Öğr. Üyesi, mutafa.nuran@deu.edu.tr Orcid: 0000-0003-2779-7980 


\title{
DİZEL ELEKTRİK SEVK SISTEMININ TARİHSEL SÜRECI
}

\begin{abstract}
$\ddot{O Z Z E T}$
Fosil yakıtların kullanımından kaynaklı zararlı gaz emisyonlarının artması çevreye geri dönüşü zor olan zararlar vermektedir. Denizcilik alanında bu etkileri azaltmak amacıyla regülasyonlar uygulanmakta ve sürekli geliştirilen bu regülasyonlara var olan konvansiyonel sevk sistemleri ile uyum sağlamak giderek zorlaşmaktadır. Özellikle çevresel faktörler göz önünde bulundurulduğunda, bu sistemlerdeki teknolojik gelişmelerin, belirli bir doygunluğa ulaşması ve yetersiz kalması, araştırmacıların elektrikli sevk sistemleri alanında çalışmaya yöneltmiştir. Bu çalışmada elektrikli sevk sistemlerinde önemli bir yere sahip olan Dizel-Elektrik sevk sisteminin süreç boyunca gelişimi ve diğer elektrikli sevk sistemleriyle karşılaştırılması yapılmaktadır. Elde edilen sonuçlara göre, dizelElektrik sevk sistemi birçok gemi tipi uygulanabilmekte, ek olarak $N O_{X}$, SOX ve $\mathrm{CO}_{2}$ emisyonlart, enerji verimliliği, yakıt tüketimi, çevrim ömrü ve maliyet açısından kazanımlar sağlamaktadır. Buna karşın ilk yatırım maliyeti bu sevk sisteminin en büyük dezavantajını oluşturmaktadır.
\end{abstract}

Anahtar Kelimeler: Elektrikli Sevk Sistemleri, Dizel-Elektrik sevk sistemi, Emisyonlar, Yakıt Tüketimi, Maliyet Etkinliği

\section{INTRODUCTION}

The ships, which were not known exactly when and by whom they were first used, have undergone many technological transformations in their thousands of years of history. The most primitive types arose as a result of the use of human force to push with different tools on floating objects. Later, wind energy played an important role in the dispatch of ships. Steam ships have come into our lives by using the vapor pressure produced by the burning of solid and liquid fuels in boilers for propulsion systems (Marsden, 1994). The fact that the energy generated by internal combustion engines rotates the propellers is still the most frequently used ship propulsion system technology today. The most important change in ship propulsion systems today is that electrical propulsion systems are being developed and applied to more and more ships. Figure 1 described the first and modern typify of using the Diesel Electric (DE) propulsion system. 


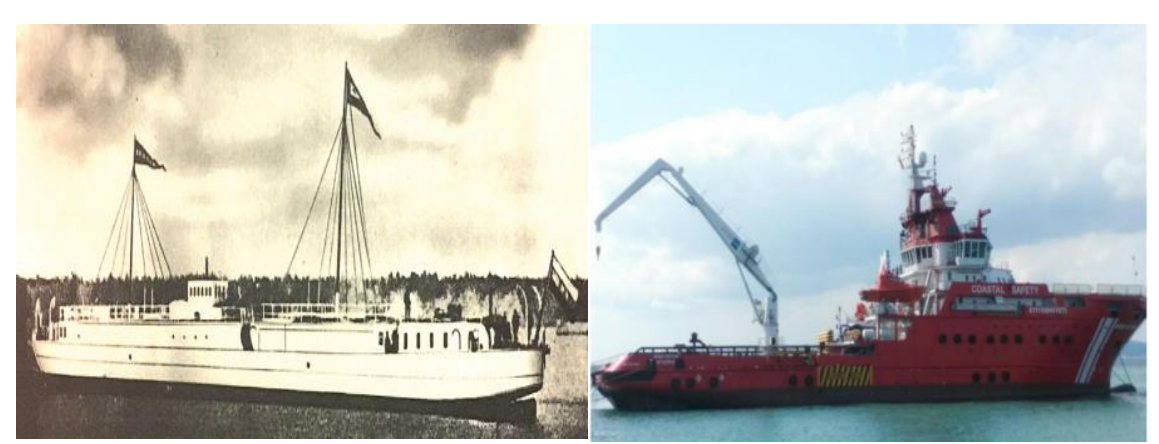

Figure 1: The First of the DE Propulsion System Vessels "Vandal" and One of the Most Modern Types "Nene Hatun"

Source: Hubbell, 2019; Kıyı Emniyeti Genel Müdürlüğü, 2016.

The historical development of electrical propulsion systems shown in Figure 2 was examined in detail by Skjong et al. (2016: 522-537). It is a literature study that explains how to get from small electric boats of the 1800 s to ships with modern electric propulsion systems. The first ship used diesel-electric propulsion system (Vandal) was launched in 1903. 


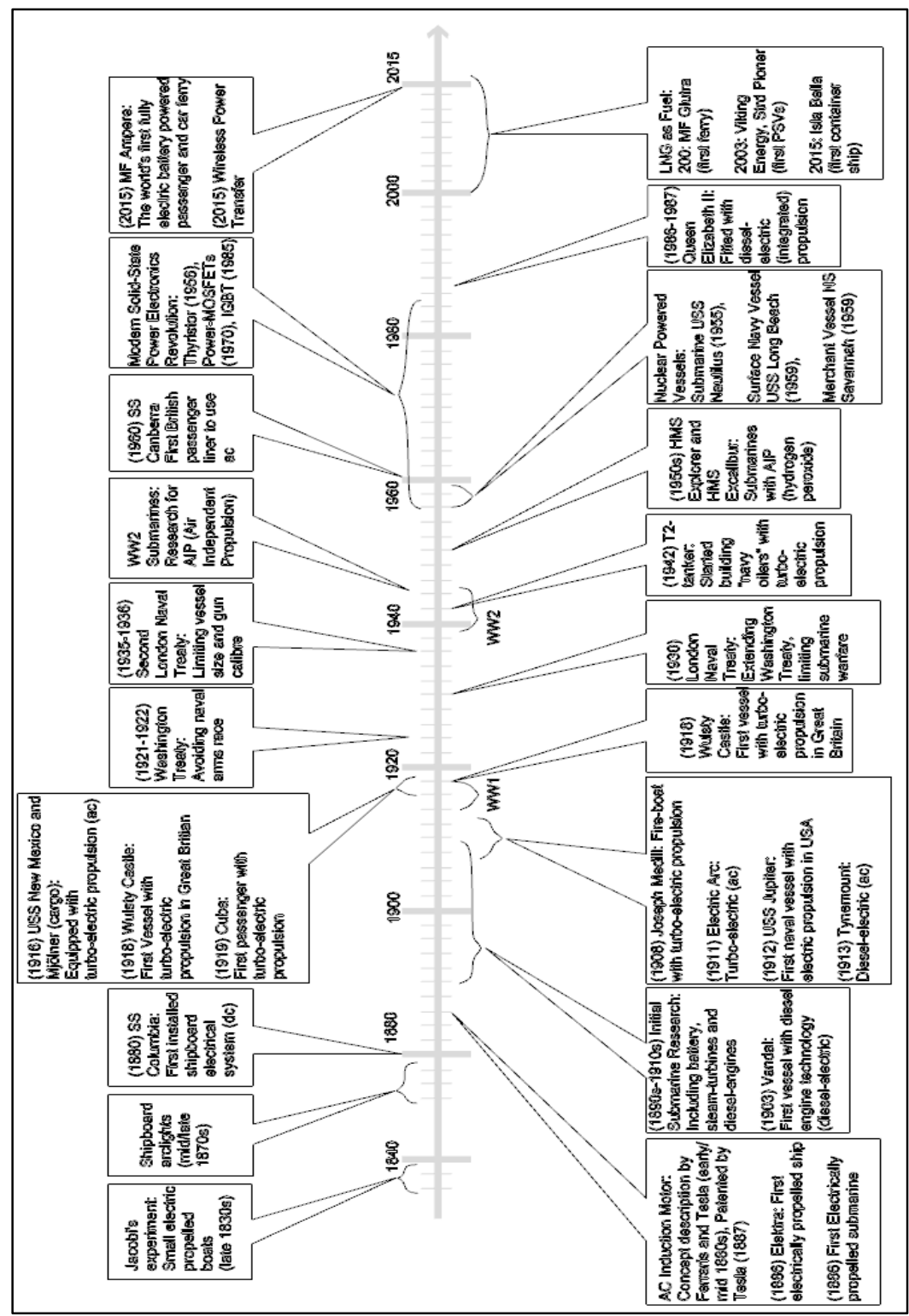

Figure 2: Historical Highlights and Developments of Marine Vessels' Power Systems, from 1830 to 2015

Source: Skjong et al., 2016.

Since then, electric ships have managed to become an important alternative to conventional propulsion systems with many changes, transformations and technological developments. In this article, the development steps of the DE propulsion system and the advantages and disadvantages of the DE propulsion system among the electrical propulsion 
systems that can be used in different ways such as fully electric, hybrid, diesel electric (DE), Combined Gas Turbine Electric and Steam (COGES) will be examined.

There are many methods used to reduce emissions on conventional ships. They are basically divided into reducing emissions at the production stage and reducing the emissions produced before they are released from the ship. The methods based on the principle of preventing emissions during production, reducing the sulfur content of the fuel used and reducing the combustion temperature. The reduction of the emissions produced before they are released from the ship, on the other hand, is the reduction of the emission rate they contain by reacting the exhaust gases with different chemical methods (Pamik et al., 2014).

All emission reduction methods have an extra cost, and many of them also increase operational costs by causing increased fuel consumption. The most important difference of electric propulsion systems is to reduce fuel consumption and prevent fuel-based emissions. In this way, it is not only an environmentally friendly method for many types of ships, but also an economical solution. In addition, every method applied for conventional systems can be applied in electrical propulsion systems if necessary (Percic et al., 2020).

However, DE propulsion systems need a good optimization and control strategy. Otherwise, the high initial investment costs of electrical equipment and, if used, extra battery costs cause this system to be unfeasible (Nguyen et al., 2020).

As with all technological developments, electric drive propulsion systems were born to meet certain needs. For trade that grows with globalization, the importance of timing and speed, the gradual decrease in fossil fuel reserves and the need for alternative fuels accordingly, the increase in global warming and environmental pollution and the regulations applied to prevent this, increasing welfare and comfort habits with technological breakthroughs, has created the need for a different propulsion system in marine transportation. Criteria such as high torque and speed capacity of electric motors, low damage to nature and compatibility with renewable sources, quieter, less vibration and high reliability have paved the way for electric propulsion systems. It has also become the most suitable solution for special ship types with precise positioning needs.

The development stages of electrical propulsion systems from 1830 to 2015 are shown in Figure 2. Special focus has been placed on the last 20 
years of the DE propulsion system. Among the articles written about the DE propulsion system for each year, primarily the articles scanned in the Web of Science (WoS) database (if not found Google Scholar), the most cited articles were selected and examined. The articles reviewed are shown in Table 1. In 2002, no reliable articles were found on the subject. Therefore, the articles written as of 2003 were examined.

\section{DE PROPULSION SYSTEM FOCUS ON LAST 20 YEARS}

In this review, studies on DE propulsion systems are examined, and it is shown in which aspects researchers have evaluated this issue in recent years. The methods used by the authors and to what extent they produced solutions were evaluated. The studies that want to show the development of the DE propulsion system and the number of citations of these studies are listed in Table 1 by years.

Tablo1: Reviewed Articles and Citation Counts

\begin{tabular}{|c|c|c|c|}
\hline & $\begin{array}{l}\text { Author } \\
\text { and } \\
\text { Years }\end{array}$ & Article Name & $\begin{array}{c}\text { Times Cited } \\
(\text { WoS })\end{array}$ \\
\hline 1 & 2003 & $\begin{array}{l}\text { Maritime electrical installations and diesel electric } \\
\text { propulsion }\end{array}$ & 249 \\
\hline 2 & 2004 & $\begin{array}{l}\text { Systems modeling for electric ship } \\
\text { design (Doctoral dissertation) }\end{array}$ & - \\
\hline 3 & 2005 & $\begin{array}{l}\text { Design of ship electric propulsion simulation } \\
\text { system }\end{array}$ & $12,(4)$ \\
\hline 4 & 2006 & $\begin{array}{l}\text { The Experience of Advanced Electric Power and } \\
\text { Propulsion Systems on Land-The Electric Ship } \\
\text { Technology Demonstrator }\end{array}$ & 1 \\
\hline 5 & 2007 & $\begin{array}{l}\text { Comparison of electric power and propulsion } \\
\text { plants for LNG carriers with different propulsion } \\
\text { systems }\end{array}$ & 6 \\
\hline 6 & 2008 & $\begin{array}{l}\text { A study on availability and safety of new propulsi } \\
\text { on systems for LNG carriers }\end{array}$ & $87,(52)$ \\
\hline 7 & 2009 & $\begin{array}{l}\text { Research on the selection of LNG carrier } \\
\text { propulsion systems }\end{array}$ & $2,(2)$ \\
\hline 8 & 2010 & $\begin{array}{l}\text { Design of hybrid diesel-electric energy storage } \\
\text { systems to maximize overall ship propulsive } \\
\text { efficiency }\end{array}$ & 8 \\
\hline 9 & 2011 & $\begin{array}{l}\text { Onboard DC Grid for enhanced DP operation in } \\
\text { ships }\end{array}$ & 89 \\
\hline
\end{tabular}




\begin{tabular}{|c|c|c|c|}
\hline & $\begin{array}{l}\text { Author } \\
\text { and } \\
\text { Years }\end{array}$ & Article Name & $\begin{array}{l}\text { Times Cited } \\
\quad(\text { WoS })\end{array}$ \\
\hline 10 & 2012 & $\begin{array}{l}\text { Assessing the potential of hybrid energy } \\
\text { technology to reduce exhaust emissions from } \\
\text { global shipping }\end{array}$ & $142,(76)$ \\
\hline 11 & 2013 & $\begin{array}{l}\text { Governor principle for increased safety and } \\
\text { economy on vessels with diesel-electric } \\
\text { propulsion }\end{array}$ & $4,(3)$ \\
\hline 12 & 2014 & $\begin{array}{l}\text { A methodology to select the electric propulsion } \\
\text { system for Platform Supply Vessels (PSV). }\end{array}$ & 5 \\
\hline 13 & 2015 & $\begin{array}{l}\text { Optimization of diesel electric machinery system } \\
\text { configuration in conceptual ship design }\end{array}$ & $31,(16)$ \\
\hline 14 & 2016 & $\begin{array}{l}\text { Comparison of COGES and diesel-electric ship } \\
\text { propulsion systems }\end{array}$ & 12 \\
\hline 15 & 2017 & $\begin{array}{l}\text { Model predictive control for hybrid diesel-electric } \\
\text { marine propulsion }\end{array}$ & $15,(8)$ \\
\hline 16 & 2018 & $\begin{array}{l}\text { Short-Circuit Fault Management in DC Electric } \\
\text { Ship Propulsion System: Protection } \\
\text { Requirements, } \\
\text { Review of Existing Technologies } \\
\text { and Future Research Trends } \\
\end{array}$ & $53,(27)$ \\
\hline 17 & 2019 & $\begin{array}{l}\text { Improved fuel-use efficiency in diesel-electric } \\
\text { tugboats with an asynchronous power generating } \\
\text { unit }\end{array}$ & $8,(3)$ \\
\hline 18 & 2020 & $\begin{array}{l}\text { Research on Simulation and Experiment of Ship } \\
\text { Complex Diesel-Electric Hybrid Propulsion } \\
\text { System }\end{array}$ & $2,(1)$ \\
\hline 19 & 2021 & $\begin{array}{l}\text { Evaluation of the environmental and economic } \\
\text { impacts of electric propulsion systems onboard } \\
\text { ships: case study passenger vessel }\end{array}$ & 0 \\
\hline
\end{tabular}

Adnanes (2003) made one of the most comprehensive studies on this subject. Based on the graph showing the fuel consumption of diesel engines according to the load, it tried to demonstrate that electrical propulsion systems can be used as more efficient systems, despite their high power transmission losses compared to conventional systems. First of all, it has made a general description of electrical propulsion systems and demonstrated all the components that should have. He showed in detail the contributions and disadvantages to the system integrity among the different alternatives. Subsequently, he presented structural and mathematical analyzes specific to Power and Propulsion Control, Electric Propulsion Drives, System Design, Harmonic Distortion. Determined design criteria 
used with methods such as Life Cycle Analysis, Failure Mode and Effects Analysis, Reliability analysis. The analysis and evaluations made were used in the last section to create sample configurations for different ship types. Finally, model was created for various ships such as Anchor Handling Tug Supply (AHTS) and Cruise with a case study.

The doctoral dissertation, which was made by Soultatis (2004), examined in detail Diesel-Electric and Gas Turbine-Electric Propulsion Systems (COGES). In these examinations, catalog data of gas turbine and diesel engine manufacturers were used as a representation. In this study, first of all, gas turbines and diesel engines as the prime movers have been compared with different approaches such as thermodynamics and fluid dynamics. What is required to generate a given power is detailed within the two prime movers. In the continuation of the study, the losses up to the propeller rotated with the power given to the electric motor for both systems were calculated. Life Cycle Cost Estimation and Reliability Analysis were performed for both systems. In the last part of the study, a velocity profile curve for merchant ships was generated and an efficiency assessment was made based on it. He stated that both systems can be used for naval ships, but the electric propulsion system will lag behind conventional multi-prime movers systems in commercial ships due to high transmission losses. He suggested that certain ship types can be advantageous with optimizations, but this technology is not a complete solution by ship owners.

Guo et al. (2005: 1059-1063) in their study, made mathematical modeling of the DE propulsion system for a tugboat. In his modeling over energy conversions, AC distribution is used. For the equipment used in the study, battery power density, efficiencies and economic evaluations were made with both the date of the study and future predictions.

Between 2006 and 2010, many studies examined the design and modeled of the DE propulsion system, LNG, Duel Fuel and Gas turbine. These studies show that although conventional diesel-mechanical systems are more efficient and more economical, a more environmentally friendly propulsion system can be designed with their compatibility with technologies such as LNG and Duel Fuel (Benatmane and Maltby, 2006: 324; Hansen and Lysebo, 2007: 24-27; Chang et al. 2008; Zuancang et al. 2009: 78-81).

Hansen et al. (2011), proposed the advantage of DC grid over AC grid for the first time in a long time in the DE propulsion system. DC grid and $\mathrm{AC}$ grid were compared in terms of the equipment required for the system and it was seen that DC grid is more advantageous both in terms of 
weight and volume. In addition, the total transmission loss has decreased with the saved equipment. It has been said that the DC grid system can reduce fuel consumption by around $20 \%$ with its compatibility with variable speed diesel engines and batteries also maintenance costs will decrease thanks to more efficient operations. It can be extremely successful in meeting the needs of Dynamic Positioning, and it could easily adapt to different power sources in the future.

Dedes et al. (2010: 703-713), (2012: 204-218) have two study that ones in 2010 and other in 2012. Their studies in 2010 is a mathematical modeling of DE propulsion system. They found the system open for improvement but not enough to cost effectives because of the high investment cost especially the battery cost. Their study in 2012, composed hybrid propulsion system installation scenarios for dry bulk ships of different sizes. They calculated that for large ships such as Cape size, it does not require a hybrid system because the engine load is close to optimum, but it can compensate investment costs in 3 to 25 years, thanks to the reduction of fuel consumption for Panamax and smaller ships. In the evaluation made in this study, sodium nickel-chlorite batteries were found effective for hybrid systems.

In the article written by Veksler et al. (2013: 2579-2584), it was stated that the use of the DE propulsion system is an inevitable necessity for ship types performing dynamic position operations. Governor modeling has been studied for a power plant with a DE propulsion system. By separating the emergency working principles with the working principle in normal times, it is aimed to reduce fuel consumption and emissions in normal situations and to ensure safe operation in case of emergency. Since there was not enough real data, mathematical modeling was contented with, and it was aimed to be able to simulate in future studies.

In the study, Morales Vásquez (2014), optimized the design of the diesel electric propulsion system for platform supply vessels (PSV) operating for platforms in Santos Basin, where oil reserves are located. For the DE propulsion system, power generation, power distribution, power storage and thrust elements have been examined in terms of efficiency, cost and system compatibility and performance analysis has been made. A case study was applied, change in fuel consumption values and emission values based on fuel consumption were calculated for PSV with the DE propulsion system. Then, financial parameters were calculated. In the last part of the study, different configurations were compared in terms of weight, volume, fuel consumption, exhaust gas emissions and costs, and Analytic Hierarchy Process (AHP) method was used. In the evaluation 
made over two scenarios where one is economic and the other is environmental factors, it was seen that medium speed generators are economically, and high-speed generators are environmentally advantageous.

In their study, Solem et al. (2015: 406-416) examined many engines in the 400-11,600 $(\mathrm{kW})$ power range, all of which have the Engine International Air Pollution Prevention (EIAPP) certificate, in order to determine a method for calculating load distribution and fuel consumption. Mathematical optimization model formulation and methods to measure the four key performance factors of their cost minimizing objective. These are investment costs, fuel costs, NOX emission taxes and area restrictions in the machinery room. Case study was conducted by applying the outputs they obtained on a tugboat. The results of this case study were not sufficient for the 5-year pay-back period, with the cost calculation generally considered by ship operators. However, it was emphasized that it will become more profitable when considering the next years. As a result, an optimization model to be used in the structuring phase of ship design is presented for decision support regarding the selection of diesel engines configuration in a DE propulsion system.

The most cited DE propulsion system article in the Web of Science database in 2016 is a continuation of the preliminary study by Veksler et al. The authors simulated the mathematical modeling they made in 2013 using real data in the Matlab program. That's why we chose to review the next most cited article for 2016. In their studies, Mrzljak and Mrakovčić (2016: 131-148) compared the DE propulsion system with the COGES propulsion system, which is systematically very similar however is separated from each other only in terms of the power generation. With the criteria of weight, size, emissions and costs, two systems were evaluated, and it was shown which one provided superiority to the other. As a result, while considering the economic factors, the DE propulsion system is found to be advantageous, while the COGES system is better when environmental factors are taken into account. In the last part, a case study was made on a cruise ship in which annual costs were calculated for both systems and it was stated that the DE propulsion system was much more advantageous.

In their study, Papalambrou et al. (2017: 11064-11069), performed diesel-electric propulsion controller modeling using 'model predictive controllers', which is a method frequently used in power system balancing models and power electronics in recent years. By comparing the experimental model with the conventional system, the reduction in gas emissions and fuel consumption has been shown. 
Satpathi et al. (2018: 272-291) in their study, emphasized the high effect of using variable speed generators and DC shipboard power system (SPS) on fuel consumption and reduction of gas emissions in ship DE propulsion systems. Despite their important advantages, it was mentioned that the DE propulsion systems and the use of DC SPS in these systems could not become widespread enough, and they examined the fault management systems for short circuit failures, which they saw as the reason for this. Because DC SPS differs from land-based direct current systems, different fault management systems have been proposed, depending on various ship operating factors such as protection system requirements, system configurations, marine missions and load conditions.

In the study conducted by Kumar et al. (2019: 565-578), models were designed for a Tug Boat in India to meet the same load requirements as fixed speed and variable speed diesel engines, and the superiority of these models in terms of fuel consumption and emissions compared to each other and conventional propulsion system. It has been demonstrated with the optimization method using Mat-Lab Simulink program. While the simulation with a variable speed motor gives the best results, it has been shown that the fixed speed DE propulsion system is also much more advantageous compared to the conventional system.

Xiao et al. (2020: 63), in their work, they simulated the DE propulsion system in the Mat-lab program. Later, they prepared a laboratory test bench where they could compare their results with their simulation values. As a result, they tried to show the margins and places of error between the two data.

Ammar and Seddiek (2021), in their study, compared two different propulsion systems for a passenger ship. They compared the battery-free DE propulsion system and the COGES system from an environmental and economic perspective. They found that while it costs around $20 \%$ higher economically, the COGES system could yield better results from an environmental point of view.

\section{RESULTS}

Among the articles on the DE propulsion system of the last 20 years, the most cited articles from the articles scanned in the web of science database (if not found Google Scholar) were examined. The articles examined are divided by years in Table 2 . The articles generally examined the DE propulsion system or compared it with different aspects of electrical 
propulsion systems such as Direct Mechanical (DM), COGES, Hybrid. The " $\sqrt{ }$ " expression in Table 2 indicates that there is a subject mentioned in the article in the year shown. " $\sqrt{ }(+)$ " and $" \sqrt{ }(-)$ " expressions also express the positive or negative effect of the mentioned feature on the DE propulsion system, respectively, or the results are better or worse when compared to other systems. 


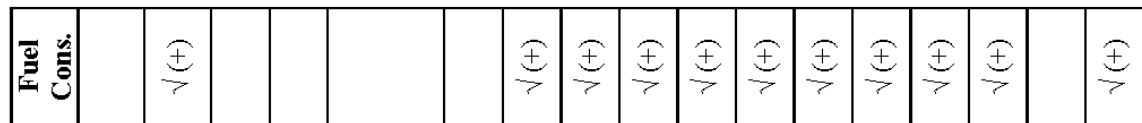

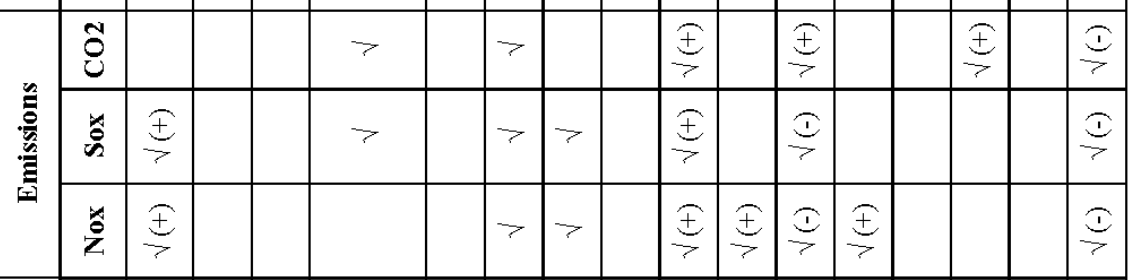

ज्ञ

吾

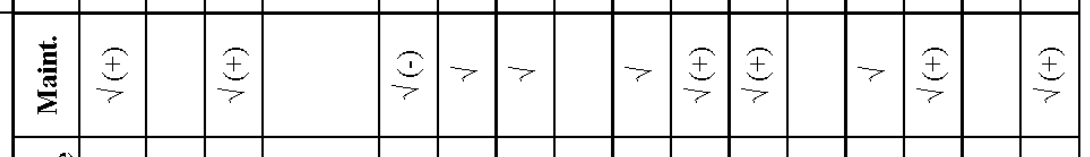

品

㐘

苛

过 $\stackrel{E}{ \pm}$

苞さ

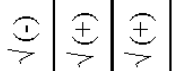

$>\underset{I}{\stackrel{I}{7}}$

密

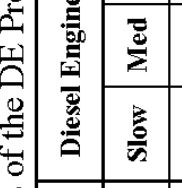

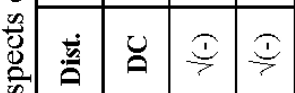

示家

氙

记芭

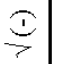

$\stackrel{ \pm}{ \pm}$

全

בั

एँ

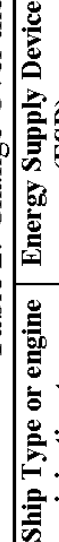

훟

离苛

눙 -

至

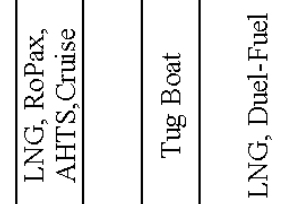

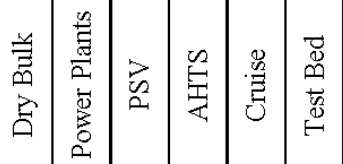

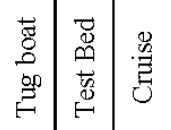

\begin{tabular}{|c|c|c|c|c|c|c|c|c|c|c|c|c|c|c|c|c|c|}
\hline \multirow{2}{*}{ 量 } & 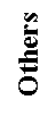 & $\sum_{\Delta}$ & $\begin{array}{l}\text { ज् } \\
\text { 엉 } \\
0\end{array}$ & & $\begin{array}{l}\text { 品 } \\
8 \\
0\end{array}$ & & & $\begin{array}{l}\text { 公 } \\
\text { 䒚 }\end{array}$ & & & & $\begin{array}{l}\text { ص } \\
\text { 뷩 } \\
0\end{array}$ & & & $\sum$ & & \\
\hline & 됭 & $>$ & $>$ & 7 & $>$ & 7 & $>$ & & 7 & $>$ & $>$ & $>$ & $>$ & $>$ & $>$ & $>$ & 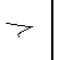 \\
\hline$\frac{2}{2}$ & & & $\sim$ & m & 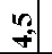 & 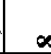 & 0 & $\Theta$ & $\Xi$ & $\approx$ & $\dddot{2}$ & \pm & 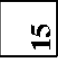 & 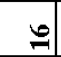 & $\approx$ & $\stackrel{\infty}{=}$ & \\
\hline
\end{tabular}


In the studies, DE propulsion system was applied or simulated on nine different ship types. In addition, two studies were experimentally studied on the test bed. Batteries and super capacitors were used as energy storage devices, and batteries were found to be more effective than super capacitors. Super-capacitors have been mentioned in some articles as being more efficient in a hybrid ESD system with a battery, but it has been concluded that they are generally costly. Li-ion batteries have been the most studied type of battery and seen as the most promising for the future. Li-ion batteries were seen as disadvantageous, especially in the old years due to their costs, but unit price which is approximately about $156 \$ / \mathrm{kWh}$ will be decreased with the developing technologies on this field. So that, this type of battery more remarkable. Not only li-ion but also the other type of batteries will be useful improving on their cost, specific energy, life cycle, weight and volume etc. (BloombergNEF, 2019). Moreover, the other electrical equipment like converters and power electronics' cost tend to decline day by day and their efficiencies are also increased.

The use of a medium speed diesel engine with the DE propulsion system was deemed appropriate, the use of the slow speed diesel engine was not recommended in any study, and the high speed diesel engine was shown to be advantageous in terms of emissions only in one study, but the high fuel consumption and maintenance costs were disadvantages are highlighted. Investment costs of the DE propulsion system were generally found to be higher than the conventional system, but it was concluded that it could be more suitable than other electrical propulsion systems. In the Life Cycle Analysis made in the studies, it has been seen as successful in general. When it is examined on the maintenance costs, it has been found useful in almost all studies. The DE propulsion system, which is in a very good condition in terms of gas emissions compared to conventional systems, gave worse results compared to only COGES. Regarding fuel consumption, which is one of the most important criteria, the DE propulsion system is seen as the most effective system for the specified ship types.

Despite all these developments, optimization of the control strategies of the system is very important in order to increase the reduction of fuel consumption and related emissions. In this way, operational efficiency can be maximized.

In most of the studies, in order to show the effect of the DE propulsion system on emissions, the fuel-based emission factors in IMO's GHG studies of the relevant years were used (Hansen et al., 2011). This does not give us a ratio of the reduced emissions but gives an idea of the amount of emissions that can be reduced from the modeled ship types. 


\section{CONCLUSION}

The process from the emergence of the DE propulsion system to the present has been examined, especially the changes and usage differences in the last 20 years have been reflected. With the technological developments and optimization of the system equipment, the costs and losses of them have decreased also their efficiency and applicability have increased. In this way fuel consumption and fuel based greenhouse gas emissions are minimized compared to the conventional system. Over the years, they have been a good alternative for many different ship types, also the gains may vary according to efficiencies, costs and ship load characteristics. Nevertheless, there is a need for specialized personnel for differentiated operational processes in the DE propulsion system. Furthermore, cargo or passenger capacity is negatively affected by creating extra weight and volume.

For future studies, along with the DC power grid and the convenience of the use of batteries, DE propulsion system can be tested for ship types (containers, etc.), which have not been studied much until today. It has been found that even with this state of the DE propulsion system, it has significant environmental advantages. Again, for future studies, some modifications can be done on the system to create compatibility for zero emission ports. This system can act as an intermediate step for the vessels to be shipped entirely with green energy or to transition to unmanned ships.

\section{REFERENCES}

Adnanes, A. K. (2003). Maritime electrical installations and diesel electric propulsion. Tutorial report, ABB AS Marine, Oslo.

Ammar, N. R., and Seddiek, I. S. (2021). Evaluation of the environmental and economic impacts of electric propulsion systems onboard ships: case study passenger vessel. Environmental Science and Pollution Research, $28,37851-37866$.

Benatmane, M., and Maltby, R. E. (2006). The Experience of Advanced Electric Power and Propulsion Systems on Land-The Electric Ship Technology Demonstrator. In: Pacific 2006 International Maritime Conference.

BloombergNEF (2019) Battery Pack Prices Fall As Market Ramps Up With Market Average At \$156/kWh In 2019. https://about.bnef.com/blog/battery-pack-prices-fall-as-market-ramps- 
up-with-market-average-at-156-kwh-in-2019/?sf113554299=1, Access Date: 15.01.2020.

Chang, D., Rhee, T., Nam, K., Lee, S., Kwak, B., and Ha, J. (2008). Economic evaluation of propulsion systems for LNG carriers: a comparative life cycle cost approach. In: GasTech 2008, Korea.

Dedes, E., Hudson, D., and Turnock, S. (2010). Design of hybrid dieselelectric energy storage systems to maximize overall ship propulsive efficiency. In: 11th International Symposium on Practical Design of Ships and Other Floating Structures. Rio de Janeiro, Universidade Federal de Rio de.

Dedes, E. K., Hudson, D. A., and Turnock, S. R. (2012). Assessing the potential of hybrid energy technology to reduce exhaust emissions from global shipping. Energy Policy, 40, 204-218.

Guo, Y., Zheng, H. Y., Wang, B. L., and Shen, A. D. (2005). Design of ship electric propulsion simulation system. In: 2005 International Conference on Machine Learning and Cybernetics. Guangzhou, China.

Hansen, J. F., and Lysebo, R. (2007). Comparison of electric power and propulsion plants for LNG carriers with different propulsion systems. In: 15th International Conference \& Exhibition on Liquefied Natural Gas. Spain.

Hansen, J. F., Lindtjørn, J. O., Vanska, K., and Abb, O. (2011). Onboard DC Grid for enhanced DP operation in ships. In: Dynamic Positioning Conference. Houston, Texas.

Hubbell. (2019). The Vandal Was the First Diesel-Electric Vessel. Waterways Journal" https://www.waterwaysjournal.net/2019/11/19/thevandal-was-the-first-diesel-electric-vessel/, Access Date: 15.01.2020.

Kıyı Emniyeti Genel Müdürlüğü. (2016). Deniz vasitalarımız. https://www.kiyiemniyeti.gov.tr/userfiles/editor/pdf/denizvas\%C4\%B1talar\%C4\%B1m\%C4\%B1z-2016.pdf, Access Date: 15.01.2020.

Kumar, B. A., Selvaraj, R., Chelliah, T. R., \& Ramesh, U. S. (2019). Improved Fuel-Use Efficiency in Diesel-Electric Tugboats with an Asynchronous Power Generating Unit. IEEE Transactions on Transportation Electrification, 5(2), 565-578. 
Marsden, P. (1994). Ships of the Port of London: first to eleventh centuries $A D$. London: English Heritage.

Morales Vásquez, C. A. (2014). A methodology to select the electric propulsion system for Platform Supply Vessels (PSV), Doctoral Dissertation, Universidade de São Paulo.

Mrzljak, V., and Mrakovčić, T. (2016). Comparison of COGES and dieselelectric ship propulsion systems. Pomorski zbornik, (1), 131-148.

Nguyen, H. P., Hoang, A. T., Nizetic, S., Nguyen, X. P., Le, A. T., Luong, C. N., ... and Pham, V. V. (2020). The electric propulsion system as a green solution for management strategy of $\mathrm{CO} 2$ emission in ocean shipping: A comprehensive review. International Transactions on Electrical Energy Systems, 31(11), e12580.

Pamık, M., Nuran, M., and Cerit, A.G. (2014) Emission Reduction Technologies for Marine Diesel Engines: A System Dynamics Approach. Dokuz Eylül Üniversitesi Denizcilik Fakültesi Dergisi, 7(1), 5574.

Papalambrou, G., Samokhin, S., Topaloglou, S., Planakis, N., Kyrtatos, N., and Zenger, K. (2017). Model predictive control for hybrid diesel-electric marine propulsion. IFAC-PapersOnLine, 50(1), 11064-11069.

Percic, M., Ancic, I., and Vladimir, N. (2020). Life-cycle cost assessments of different power system configurations to reduce the carbon footprint in the Croatian short-sea shipping sector. Renewable and Sustainable Energy Reviews, 131, 110028.

Satpathi, K., Ukil, A., and Pou, J. (2018). Short-circuit fault management in DC electric ship propulsion system: protection requirements, review of existing technologies and future research trends. IEEE Transactions on Transportation Electrification, 4(1), 272-291.

Skjong, E., Volden, R., Rødskar, E., Molinas, M., Johansen, T. A., and Cunningham, J. (2016). Past, present, and future challenges of the marine vessel's electrical power system. IEEE Transactions on Transportation Electrification, 2(4), 522-537.

Solem, S., Fagerholt, K., Erikstad, S. O., and Patricksson, Ø. (2015). Optimization of diesel electric machinery system configuration in conceptual ship design. Journal of Marine Science and Technology, 20(3), 406-416. 
Soultatis, C. (2004). Systems modeling for electric ship design, Doctoral dissertation, Massachusetts Institute of Technology.

Veksler, A., Johansen, T. A., Mathiesen, E., and Skjetne, R. (2013). Governor principle for increased safety and economy on vessels with diesel-electric propulsion. In: 2013 European Control Conference (ECC). Zürich, Switzerland.

Xiao, N., Xu, X., and Chen, B. (2020). Research on Simulation and Experiment of Ship Complex Diesel-Electric Hybrid Propulsion System. Journal of Ship Research, 64(2), 171-184.

Zuancang, L., Yulong, Z., and Qinming, T. (2009). Research on the selection of LNG carrier propulsion systems. In: 2009 Pacific-Asia Conference on Knowledge Engineering and Software Engineering. IEEE.

\section{NOMENCLATURE}

AHP: Analytic Hierarchy Process

AHTS: Anchor Handling Tug Supply

COGES: Combined Gas Turbine Electric and Steam

DE: Diesel-Electric

EIAPP: Engine International Air Pollution Prevention

ESD: Energy Supply Device

PSV: platform supply vessels

SPS: Shipboard Power System

WoS: Web of Science 